\title{
Timing of the Cathaysia Block formation: Constraints from SHRIMP U-Pb zircon geochronology
}

\author{
Guangzhou Institute of Geohemistry, Chinese Academy of Sciences, Guangshou 510640, China
}

Geochemical data and SHRIMP U-Pb zircon isotopic age of $1766 \pm 19 \mathrm{Ma}$ are reported for the amphibolites exposed in NW Fujian-SW Zhejiang and generally accepted as the oldest rocks in the Catharsia Block. These data, combined with previous $U-P b$ zircon and $N d$ isotopic studies for the gineissic granites in the region, provide new constraints on the crustal evolution of the Cathaysia Block. It is therefore concluded that the Cathaysia Block was most likely formed at $1.77 \mathrm{Ga}$ through cratonization by granite formation as the result of recrystallization of crustal materials derived from an Archean provenance, which was probably triggered by the intraplate basaltic magmatism.

\section{Introduction}

The southeastern part of China is lectonically divided into two major blocks: Yangt/e Block to the northwest and Cathaysia Block to the southeast (Figure 1). The crustal evolution of the Cathaysia Block has been an issuc of long-term debate. Grabau (1923) first proposed a Precambrian "Cathaysia old land" which refers to the metamorphic basement rocks unconformably underlying the Devonian sandstome in Fujian and Zhejiang Provinces. SE China. The existence of the Precambrian Cathalysia old land was further supported by Chan (1956) and Zhang (1959). Alternatively, southeastem China was described als Caledonian geosyncline rather than Precambrian Cathaysia Block by Xie (1961), Huang (1977), and Ren et al. (1987). A model of multiple-stage island-arc accretions for the crustal evolution of SE China was proposed by Guo et al. (1980). which also precludes the existence of the Precambrian Cathaysia Block. In the past few years, however, the existence of the Paleoproterozoic-mid-Mesoproterozoic Cathaysia Block has gained increasing acceptance largely due to the enormous amount of radiometric work in the region (e.g., Shui. 1987: Jahn et al.. 1990; Hu et at., 1991: Li et al., 1992: Gan et a1.. 1993. 1995). Furthermore, a few workers deduced the Cathaysia Block as old as Archean in terms of $\mathrm{Sm}-\mathrm{Nd}$ isochron and inherited rircon U-Pbages (Fu et al. 1991: 7hou, 1997). The debate on the timing of the (athaysia Block formation and its evolution, is largely attributed to the complex of geology of the region. On the other hand, the lack of precise radiometric age data for the key rock units has confused the debate.
In this paper. new SHRIMP U-Pb zircon age data for the amphibolites with a depth of about seven meters from Tianjinping. NW Fujian, which, together with the previously published isotopic data. enable new constraints to be placed on the timing of the Cathaysia Block formation.

\section{Geologic background}

Precambrian basement of the Cathaysia Block comprises two metamorphic sequences that are mainly exposed in an area between Jiangshan-Shaoxing and Lishui-Haifeng Faults, SW Zhejiang-NW Fujian Provinces (Figure 1). The lower sequence with a total thickness of $\sim 3600 \mathrm{~m}$, which termed as the Badu Group in Zhejiang and the Mayuan Group in Fujian. consists mainly of leptynites, schists, gneissic granites and metamorphosed volcanics. Amphibolites are mainly associated with biotite leptynites and gneissic granites. The latter crops out mostly in the Tangyuan Formation (the lowest part of the Badu Group), and displays transitional relationship with the surrounding leptynites, with a few of gneissic granite plutons showing intrusive contacts with the country rocks (Hu et al., 1991). These

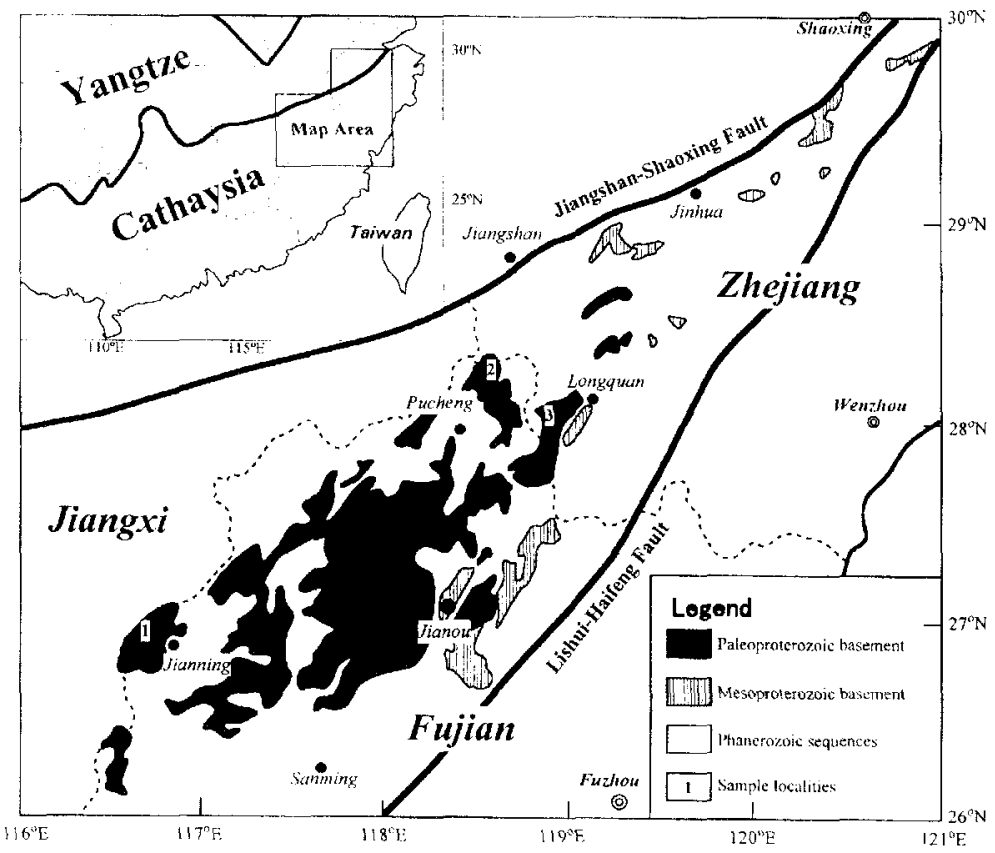

Figure I Simplified geologic map of the Cathaysia Block showing Precambrian basement distribution (modified after Hu et al., 1992 \& Gan et al., 1993). Sample localities I, 2 and 3 are Tianjinping of Jianning County, Xinan of Pucheng County and Zhulu of Longquan County, respectively, where amphibolite samples were collected for zircon $U-P b$ and major and trace element analyses reported in this study. 
rocks undencit relatively higher grade regional metamorphism of amphibolite ficies. The upper sequence with a thickness of more than $2000 \mathrm{~m}$. named as the Longquan Group in Zhejiang and the Mamianshan Group in Fujian, dominantly comprises volcanic sediments including schists. meta-voleanies. Fe-bearing quartzites and marbles. These rocks were metamorphosed to relatively lower grade of greenschist facies (Hu et al., 1991 : Jin et al.. 1992).

\section{Previous radiometric age data}

In the past few years, a number of U-Pb zircon ages clustering around 1.74 1.98 Ga for gneissic granites within the Badu Group have been reported. including granites at Xiaji (1975 $\pm 80 \mathrm{Ma})$,

Table 1 Selected chemical analyses of amphibolites from NW Fujian and $S W$ Zhejiang, the Cathaysia Block

\begin{tabular}{|c|c|c|c|}
\hline & $\begin{array}{c}\text { LG24 } \\
\text { Tianjinping }\end{array}$ & $\begin{array}{c}\text { LB } 117 \mathrm{~B} \\
\text { Xi nan } \\
\text { Mayuan }\end{array}$ & $\begin{array}{l}\text { L13261 } \\
\text { Zhulu } \\
\text { Badu }\end{array}$ \\
\hline $\mathrm{SiO}_{2}$ & 48.31 & 49.46 & 48.17 \\
\hline $\mathrm{IiO}_{2}$ & 2.56 & 2.02 & 1.82 \\
\hline $\mathrm{Al}_{2} \mathrm{O}_{3}$ & 17.00 & 15.70 & 17.02 \\
\hline $\mathrm{Fe}_{2} \mathrm{O}_{3}$ & 2.59 & 2.14 & 5.58 \\
\hline $\mathrm{FeO}$ & 10.38 & 9.75 & 6.50 \\
\hline $\mathrm{MnO}$ & 0.19 & 0.18 & 0.17 \\
\hline $\mathrm{MgO}$ & 4.48 & 5.00 & 5.25 \\
\hline $\mathrm{CaO}$ & 7.33 & 7.65 & 9.47 \\
\hline $\mathrm{Na}_{2} \mathrm{O}$ & 4.08 & 3.09 & 3.31 \\
\hline $\mathrm{K}_{2} \mathrm{O}$ & 1.11 & 1.47 & 0.96 \\
\hline $\mathrm{P}_{2} \mathrm{O}_{3}$ & 0.32 & 0.38 & 0.24 \\
\hline Loss & 1.52 & 2.84 & 1.47 \\
\hline Sumn & $\overline{99.87}$ & $\overline{99.68}$ & $\overline{9996}$ \\
\hline $\mathrm{Sc}$ & 19.0 & 28.6 & 34.5 \\
\hline V & 184 & 325 & 249 \\
\hline C.r & 78.7 & 55.8 & 689 \\
\hline $\mathrm{Co}$ & 419 & 37.9 & 50.1 \\
\hline $\mathrm{Ni}$ & 38.0 & 50.5 & 245 \\
\hline $\mathrm{Cu}$ & 57.7 & 66.5 & 3.03 \\
\hline$Z_{n 1}$ & 119 & 118 & 77.3 \\
\hline Gia & 22.7 & 22.6 & 22.2 \\
\hline Ge & 1.69 & 2.05 & 1.99 \\
\hline$k b$ & 32.5 & 62.5 & 40.4 \\
\hline$S_{\Gamma}$ & 448 & 348 & 315 \\
\hline$Y$ & 26.7 & 273 & 28.6 \\
\hline $\mathrm{Zr}$ & 191 & 153 & 159 \\
\hline $\mathrm{Nb}$ & 17.1 & 35.5 & 17.4 \\
\hline$C 5$ & 3.60 & 5.12 & 2.85 \\
\hline $\mathrm{Ba}$ & 469 & 333 & 155 \\
\hline $\mathrm{La}$ & 17.6 & 25.5 & 201 \\
\hline $\mathrm{Cc}$ & 42.7 & 55.8 & 420 \\
\hline $\operatorname{Pr}$ & 5.81 & 6.93 & 528 \\
\hline $\mathrm{Nd}$ & 250 & 27.9 & 209 \\
\hline $\mathrm{Sm}$ & 6.21 & 5.61 & 197 \\
\hline$E u$ & 2.40 & 1.73 & 1.97 \\
\hline Gd & 6.73 & 5.43 & 5.11 \\
\hline Tb & 1.02 & 0.88 & 0.89 \\
\hline Dy & 5.95 & 4.97 & 4.77 \\
\hline Ho & 1.16 & 0.99 & 1.05 \\
\hline Er & 3.13 & 2.66 & 2.94 \\
\hline Tm & 0.43 & 0.38 & 11.42 \\
\hline $\mathrm{Yb}$ & 2.65 & 2.26 & 2.64 \\
\hline $\mathrm{Lu}$ & 0.39 & 0.33 & 0.41 \\
\hline $\mathrm{Hf}$ & 4.54 & 3.52 & 3.88 \\
\hline $\mathrm{Ta}$ & 0.99 & 2.112 & 1.05 \\
\hline $\mathrm{Pb}$ & 7.39 & 8.46 & 8.11 \\
\hline $\mathrm{Th}$ & 2.00 & 2.96 & 3.14 \\
\hline$[\mathrm{i}$ & 0.67 & 1.19 & 0.95 \\
\hline
\end{tabular}

Major elements (w1\%) of the samples were measured by wet chemistry Trace elenent concentrations $(\mu g / g)$ were determined using PF. Flan 6000 ICP-MS at Guangzhou Institute of Geochemistry, Chinese Academy of Sciences. The ICP-MS analytical procedures used were similar to those reported by Liu et al (1996).

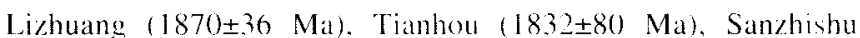

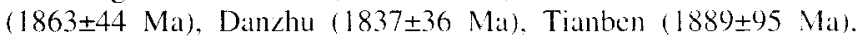
Quankeng $\left({ }^{207} \mathrm{~Pb} /{ }^{2}(6) \mathrm{Pb}\right.$ age $\left.=175.5 \pm 3 \mathrm{Ma}\right)$. and Zhukou Pegmatite $\left({ }^{207} \mathrm{~Pb} /{ }^{206} \mathrm{~Pb}=1743 \pm 8 \mathrm{Ma}\right)$ (Hu et al. 1992: Gan et al., 1993. 1945). As these gneissic granites were either transitional to the surrounding leptynites, or intruded into leptynites and schists, the age of 1.74 1.98 Ga have been interpreted as the upper limit of the formation age of the Badu Group. However, all these U-Pb data are hishly discordant and display significant $\mathrm{Ph}$ loss subsequent to the gramite formation. All the above zircon U-Ph ages, except $\mathrm{two}{ }^{207} \mathrm{Ph} / 2(1+\mathrm{Pb}$ ages of $\sim 75 \mathrm{Ga}$ are upper-intercept ages rather than concordant ages.

A Sm-Nd isochron age of $2682 \pm 148$ Ma for the amphibolites from Tianjinping. NW Fujian was reported and therefore considered as the convincing evidence for the existence of late Archean crust in the Cathaysia Block (Fu el al., 1991). The reported Sm-Nd restession line. however, is most likely an errorchron rather than an isochron, because all the analyzed samples have a very linited ${ }^{147} \mathrm{Sm} /{ }^{144} \mathrm{Nd}$ variation ranging from 0.1432 to 0.1557 and an unreasonably high initial $\varepsilon N d$ value of +8.7 at 2.7 Ga. Thus, the date of 2.7 Ga for the amphibolite has been questioned and considered to be geologically meaningless (I.i. 1996).

\section{Geochemical characters of amphibolites}

The Tianjinping amphibolite is almost the same in lithology and geochemistry as the amphibolites within the Badu and Mayuan Groups (Table 1). They are mainly composed of $55-60 \%$ amphibole and $45-40 \%$ plagioclase $\left(\mathrm{An}_{43-7 x}\right)$ with minor amount of magnetite. ilmenite, zircon and monazite. The amphibolites have basaltic compositions. Because the samples are metamorphosed and the mobile elements (such as $\mathrm{K}$. Na. Rb. Sr, Ba. ctc) are susceptible to change during metamorphism. they are not classified further on an alkali$\mathrm{SiO}_{2}$ diagram. However. on a $\mathrm{Zr} / \mathrm{TiO}{ }_{2}-\mathrm{Nb} / \mathrm{Y}$ diagram (Winchester and Floyd. 1976) in which all elements are not as susceptible as the above mobile elements. the amphibolite samples mostly plot within alkali basalt field (figure is not shown). They are enriched in incompatible elements, including the light rare-earth elements with (La/Yb) ${ }_{n}$ ratios up to 10 . On a MORB-nomalized trace element distribution spiderdiagram of Pearce (1982), all the amphibolite samples have similar "humped" patterns, which are characterised by variable enrichment in all the trace clements except $\mathrm{Y}$ and $\mathrm{Yb}$ rotattive to average MORB (Figure 2). This resembles many athali basalts formed in oceanic islands and continental rift area. The geochemical similarity indicates that amphibolites from different localities of NW Fujian-SW Zhejiang might have been derived from a similar mantle source. Obviously. there is no compelling evidence to subdivide the Tianjinping amphibolite into an Archean rock unit proposed by Fu et al. (1991), contrasting to those Paleoproterozoic amphibolites within the Mayuan and Badu Groups (Hu et al., 1992; Gan e1 al. 1909, 1905).

\section{SHRIMP U-Pb zircon geochronology}

The amphibolite sample uned in this study was collected from tian jimping. Jianning County of NW foujian Province. The whole rock sample was crushed and pulveriad down $0<<250 \mu \mathrm{mm}$ in an alloy mill, carefully washed. and separated through standard mineral separation procedures including gravitational and magnetic technigues. Zircon grains were then handpicked from the final concentrate. Most zircons from the Tianjinping amphibolice are light brown. euhciral to subhedral, and stubby with length/width ratios of about 2:1. Somc grains, however. show a central brown core surrounded by a unbid or thin, clear overgrowth. Occasionally. dark-brown anhedral zircon grains were observed. Representative zircon grains were loaded onto an epoxy mount. which was then polished to section the fircon? grains in half. $\mathrm{U}-\mathrm{Pb}$ isotopic determination was undertaken on the 
Table 2 SHRIMP U-Pb zircon geochronological data for amphibolite from Tianjinping, the Cathaysia Block

\begin{tabular}{|c|c|c|c|c|c|c|c|c|c|c|}
\hline Site & $\begin{array}{c}\mathrm{U} \\
(\mu \mathrm{g} / \mathrm{g})\end{array}$ & $\begin{array}{c}\text { Th } \\
(\mu g / g)\end{array}$ & $\mathrm{Th} / \mathrm{U}$ & $\begin{array}{l}{ }^{2014} \mathrm{~Pb} \\
(\mathrm{ng} / \mathrm{g})\end{array}$ & $\begin{array}{l}\text { Comm } \\
{ }^{206} \mathrm{~Pb}(\%)\end{array}$ & ${ }^{206} \mathrm{~Pb} /{ }^{238} \mathrm{U}$ & ${ }^{207} \mathrm{~Pb} /{ }^{235} \mathrm{U}$ & ${ }^{207} \mathrm{~Pb} /{ }^{206} \mathrm{~Pb}$ & $\begin{array}{l}\mathrm{Age}^{a} \\
(\mathrm{Ma})\end{array}$ & Disc. \\
\hline $1-1$ & 26 & 48 & 1.81 & 2 & 0.24 & $0.481 \pm 16$ & $12.82 \pm 0.51$ & $0.1933+32$ & $2770 \pm 27$ & 91 \\
\hline $1-2$ & 27 & 52 & 1.95 & $<1$ & 0.11 & $0.509 \pm 18$ & $13.40 \pm 0.60$ & $0.1847 \pm 45$ & $2696 \pm 41$ & 101 \\
\hline $2-1$ & 51 & 37 & 0.74 & 3 & 0.37 & $0.312 \pm 10$ & $4.59+0.19$ & $0.1067 \pm 23$ & $1745 \pm 40$ & 100 \\
\hline $2-2$ & 59 & 45 & 0.76 & 8 & 0.82 & $0.307 \pm 10$ & $4.61 \pm 0.19$ & $0.1088 \pm 24$ & $1780 \pm 40$ & 97 \\
\hline $3-1$ & 177 & 72 & $0.4 !$ & 5 & 0.13 & $0.358+12$ & $6.16 \pm 0.21$ & $0.1248+10$ & $2026 \pm 14$ & 97 \\
\hline $4-1$ & 71 & 33 & 0.16 & 3 & 0.22 & $0.291 \pm 09$ & $4.41 \pm 0.17$ & $0.1097 \pm 17$ & $1795+29$ & 92 \\
\hline $5-1$ & 158 & 239 & 1.52 & 145 & 3.71 & $0.434 \pm 14$ & $9.44 \pm 0.35$ & $0.1577+24$ & $2432 \pm 26$ & 96 \\
\hline $6-1$ & 160 & 86 & 0.54 & 9 & 0.18 & $0.535 \pm 17$ & $14.67 \pm 0.49$ & $0.1990 \pm 10$ & $2818 \pm 08$ & 98 \\
\hline $7-1$ & 137 & 113 & 0.82 & 2 & 0.08 & $0.292 \pm 09$ & $4.36 \pm 0.15$ & $0.1084 \pm 11$ & $1773 \pm 19$ & 93 \\
\hline $8-1$ & 93 & 89 & 0.95 & 4 & 0.27 & $0.300 \pm 10$ & $4.50 \pm 0.16$ & $0.1086 \pm 15$ & $1776 \pm 25$ & 95 \\
\hline $9-1$ & 80 & 62 & 0.78 & 1 & 0.09 & $0.304 \pm 10$ & $4.73 \pm 0.17$ & $0.1128 \pm 16$ & $1845 \pm 26$ & 93 \\
\hline $10-1$ & 188 & 217 & 1.15 & 7 & 0.23 & $0.287 \pm 09$ & $4.21 \pm 0.15$ & $0.1063 \pm 11$ & $1737 \pm 18$ & 94 \\
\hline $11-1$ & 90 & 91 & 1.02 & 5 & 0.35 & $0.317 \pm 10$ & $4.77 \pm 0.18$ & $0.1091 \pm 16$ & $1784 \pm 28$ & 100 \\
\hline $12-1$ & 39 & 52 & 1.34 & 3 & 0.44 & $0.321 \pm 11$ & $4.75 \pm 0.21$ & $0.1075 \pm 28$ & $1757 \pm 26$ & 102 \\
\hline
\end{tabular}

$\mathrm{U}-\mathrm{Pb}$ ages are corrected for common lead. Uncertinties are given at the $1 \sigma$ level. Comm. ${ }^{206} \mathrm{~Pb}=$ amount of ${ }^{206} \mathrm{~Pb}$ that is $\mathrm{common}$; Disc, $=$ discordancy $\left\{\left({ }^{206} \mathrm{~Pb} / 23 \times \mathrm{Pb}\right.\right.$ age $) /\left({ }^{207} \mathrm{~Pb} / 206 \mathrm{~Pb}\right.$ age $\left.)\right\} \times 100 . \quad$ Age $={ }^{207} \mathrm{~Pb} / 206 \mathrm{~Pb}$ age

exposed zircons using the SHRIMP-II ion microprobe at the Research School of Earth Sciences, Australian National University. The detailed procedures of the SHRIMP analysis have been given in Williams and Clacsson (1987).

Fourteen analyses have been obtained for the amphibolite samples (Table 2), and most of which have low $\mathrm{U}$ concentrations, with nine being $<100 \mathrm{ppm}$, significantly lower than those in normal granites. Consequently, the radiogenic $\mathrm{Pb}$ concentrations are low, which result in comparatively large analytical errors in the measured isotopic ratios. Eight out of fourteen analyses give indistinguishable ${ }^{207} \mathrm{Ph} / 206 \mathrm{~Pb}$ ratios within analytical errors and correspond to a weighted mean ${ }^{207} \mathrm{~Pb} / 206 \mathrm{~Pb}$ age of $1766 \pm 19 \mathrm{Ma}(2 \sigma)$ (Figure 3). This ircon $\mathrm{U}-\mathrm{Pb}$ age of $1766 \pm 19 \mathrm{Ma}$ is interpreted as the crystal- lization age of the amphibolite for the following reasons: (1) The analyzed zircon grains are euhedral and prismatic, and contain low $U$ and Th, which are typical of magmatic origin from a mantle-derived low $U$ and Th melt. (2) The best domains within a single zircon grain were chosen for analysis using ion microprobe. with cracks and inclusions which are most susceptible to $\mathrm{Pb}$ loss being eliminated. (3) The main group of analyses are concordant within analytical errors, displaying a simple age population.

Five analyses (1-1, 1-2,3-1,5-1 and 6-1) were perfromed on either rounded cores or dark-brown anhedral zircon grains. These analyses yicld at significantly older ${ }^{207} \mathrm{~Pb} / 206 \mathrm{~Pb}$ age ranging from $2026 \pm 14 \mathrm{Ma}$ to $2818 \pm 8 \mathrm{Ma}$, thus being interpreted as the ages of inherited zircons which were likely assimilated during crystallization of the basaltic magmat.

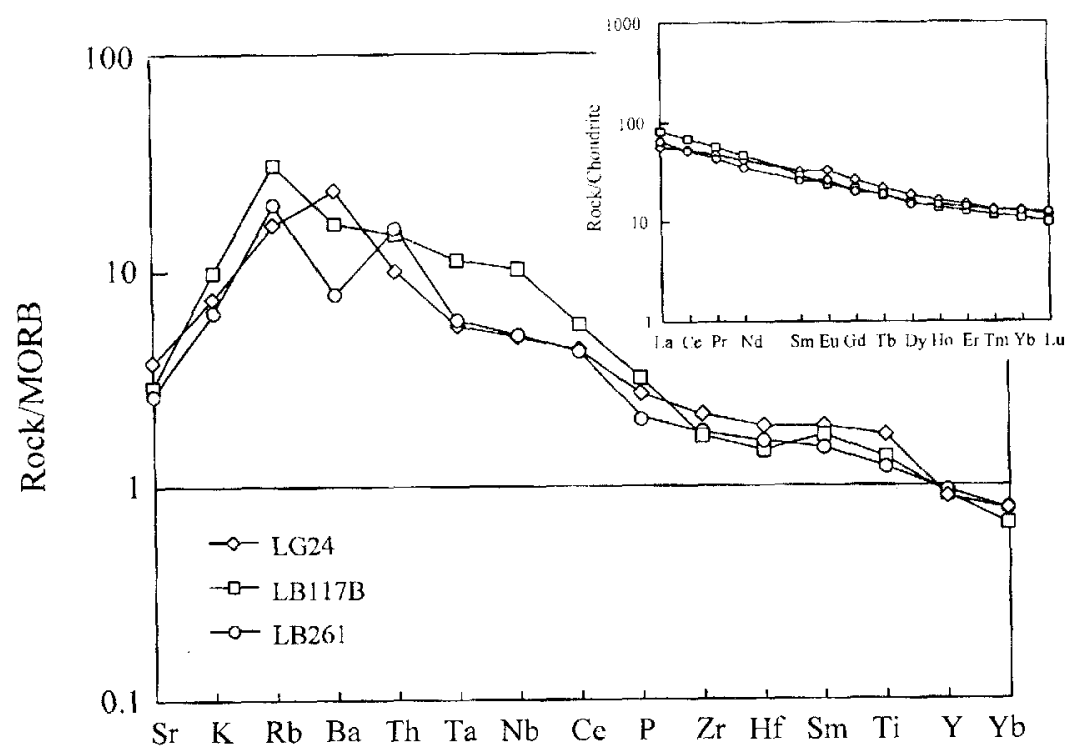

Figure 2 MORB-normalized incompatible element spiderdiagram of Pearce (1982) and chondrite-normalized REE patterns (inset) for amphibolites in NW Fujian-SW Zhejiang.

\section{Discussion}

SHRIMP U-Pb zircon results indicate that the Tianjinping amphibolite was crystallized at $1766 \pm 19$ Ma, precluding the existence of Archean volcanic rocks in the region. Furthermore, this SHRIMP U$\mathrm{Pb}$ zircon age is roughly similar to, but slightly younger than. the previously published U-Pb zircon ages of $1.74 \sim 1.98 \mathrm{Ga}$ for gneissic granites within the Badu Group (Hu et al., 1992; Gan et al., 1993. 1995). This small age difference indicates that the Tianjinping amphibolites are probably slightly younger than those within the Badu Group. Alternatively, all the amphibolite is likely coeval in terms of their field relationship and geochemical characteristics mentioned above.

It is worth to note that the U-Pb zircon isotopic system in crusi-derived granites is usually complicated and characterized by inherited radiogenic $\mathrm{Pb}$ and secondary $\mathrm{Pb}$ loss during subsequent geological events (e.g. Paterson et al. 1992; Williams, 1992; Li et al.. 1996). In such complicated zircons, highly discordant $\mathrm{U}-\mathrm{Pb}$ age data obtained by the 


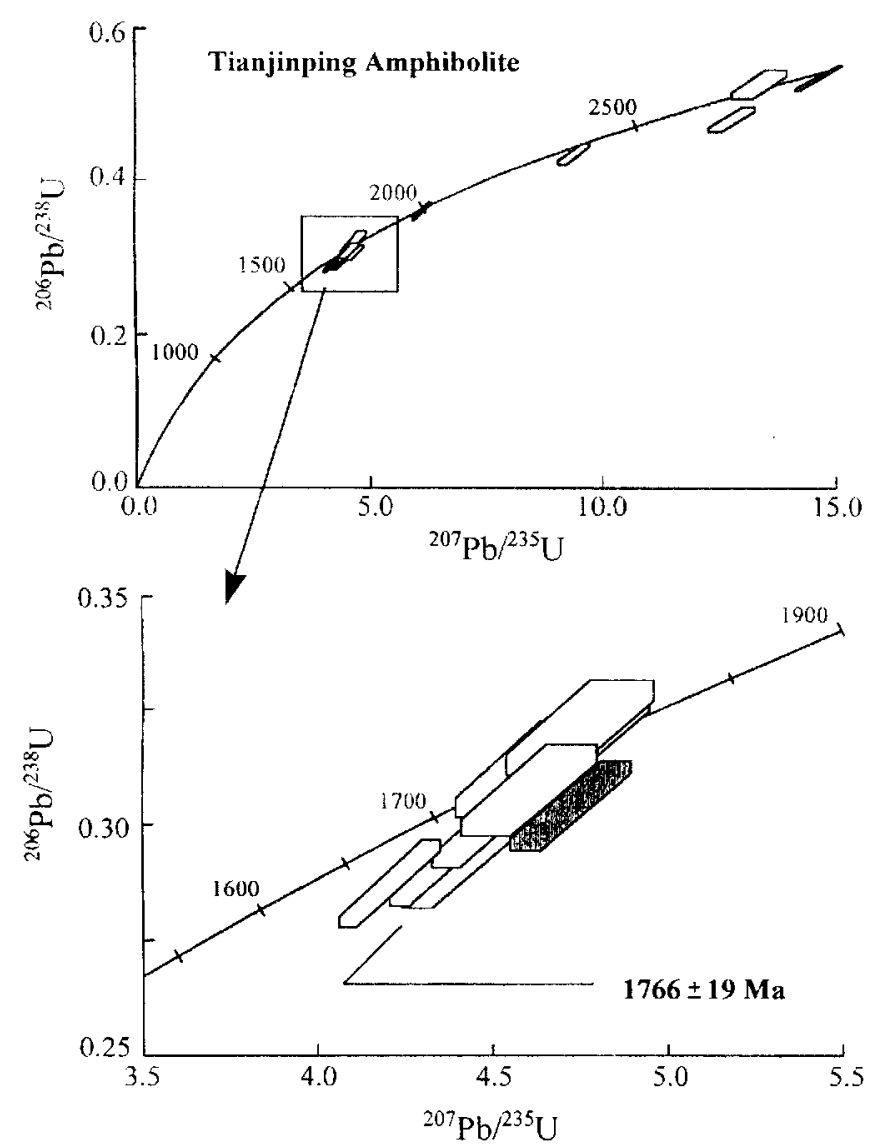

Figure 3 SHRIMP U-Pb zircon concordia diagram for the Tianjinping amphibolite.

means of conventional multi-grain zircon $\mathrm{U}-\mathrm{Pb}$ analysis usually result in an upper-intercept age which may differ from the real crystallization age to varying degrees. In other words, in order to precisely determine the crystallization age, it is crucial to obtain concordant $\mathrm{U}-\mathrm{Pb}$ zircon age by ion microprobe and single-grain zircon $\mathrm{U}-\mathrm{Pb}$ dating techniques. As mentioned in earlier section, all the $\mathrm{U}-\mathrm{Pb}$ data for the gneissic granites within the Badu Group are highly discordant, and only the upper-intercept ages with large errors, rather than concordant ages, have been obtained. These upper intercept ages are ustally older than those measured ${ }^{207} \mathrm{~Pb} / 206 \mathrm{~Pb}$ ages. It is tentatively suggested based on the field relations and the published age data that these granitic gneisses were likely formed at late Paleoproterozoic, either coeval with, or slightly younger than the amphibolites of $1.77 \mathrm{Ga}$. Further zircon U-Pb analysis, especially the SHRIMP zircon U-Pb analysis, is very much needed in order to obtain the precise crystallization age of these gneissic granites.

SHRIMP zircon U-Pb analysis in this study gives some inherited zircons of early Paleoproterozoic to late Archean ages in the Tianjinping amphibolite, indicating the existence of late Archean crustal components in the Cathaysia Block. Inherited zircons in ages of 2.5-2.7 Ga have also been recognized in some Phanerozoic granites ( $\mathrm{Li}$ et al., 1989; Gan et al, 1996). Previously published Nd isotope data for these gneissic granites yield consistent late Archean Nd model ages ranging from 2.5 to $2.8 \mathrm{Ga}$ (Hu et al., 1991; Wang et al., 1992), suggesting a source with late Archean crust residence ages for these gneissic granites. These isolopic data imply that the early crustal components in the Cathaysia Block were derived from an Archean provenance. However, there has been no compelling geological and radiometric evidence so far for any outcrops of the late Archean crystalline basement rocks. The amphibolites of $1766 \pm 19$ $\mathrm{Ma}$ and the nearly contemporaneous gneissic granites are known as the oldest crystalline basement rocks in the Cathaysia Block.

\section{Concluding Remarks}

SHRIMP zircon $\mathrm{U}-\mathrm{Pb}$ analysis yields a precise crystallization age of $1766 \pm 19$ Ma for the Tianjinping amphibolite in NW Fujian. Ficld relationship and gcochemical characters suggest that the amphiholites, the oldest crystalline basement rocks exposed in NW FujianSW Zhejiang of the Cathaysia Block, are most likely coeval. Although a few of zircon $\mathrm{U}-\mathrm{Pb}$ upper-intercept ages of $1.8 \sim 1.98 \mathrm{Ga}$ have been previously reported for the gneissic granites within the Badu Group, it is argued that these gneissic granites are either contemporaneous with or slightly younger than the amphibolites in terms of their field relations and the uncertainties of the highly discordant $\mathrm{U}-\mathrm{Pb}$ ages for the crust-derived granites. Existence of the Archean crustal components is suggested in the Cathaysia Block based on both inherited zircon $\mathrm{U}-\mathrm{Pb}$ ages for the Tianjinping amphibolie and $\mathrm{Nd}$ model ages for the granitic gneisses within the Badu Group. However, there has been no compelling evidence for existence of the late Archean crystalline basement rocks

The SHRIMP zircon U-Pb analysis in this study provides important radiometric constraints on the crustal evolution of the Cathaysia Block. The Cathaysia Block was most likely formed at 1.77 Ga through cratonization by granite formation as the result of recrystallization of crustal materials derived from an Archean provenance, which was probably triggered by the intraplate basaltic magmatism.

\section{Acknowledgements}

Prof. W. Compston is particularly acknowleged for access to SHRIMP laboratory at RSES, Australian National University during my visit in 1992-1993. Thanks are also extended to R. Reinfrank. Y. Liu, H.C. Liu for technical assistance. H. Zhang for zircon separation, and J.-X. Zhao for processing the SHRIMP data. This study was supported by the NSFC grant and a special support fund of the Chinese Academy of Sciences (951163).

\section{Reference}

Chan, K.-D., 1956. Examples of "activizing region" in the Chinese platform with special reference to the "Cathaysia" problem: Acta Geologica Sinica, vol. 36, no. 3, pp.239-272 (in Chinese with English abstract).

Fu, S., Chen, J., and Lin, W., 1991, Geological characteristics of UpperArchaeozoic Tianjinping Formation $\mathrm{Ar}_{2} \mathrm{t}$ in Western Jianning. Fujian Province: Geology of Fujian, vol. 10, no. 2, pp.103-113 (in Chinese with English abstract).

Gan, X.. Li, H., Sun. D., Jin. W, and Thao. F., 1995. A geochronological study on early Proterozoic granitic rocks, southeastern Zhejiang: Acta Petrologica et Mineralogica, vol. 14, no. 1, pp.1-8 (in Chinese with English abstract).

Gan, X., Li, H., Sun, D., and Zhuang, I. 1993, Geochronology of the Precambrian basement in northem Fujian: Geology of Fujian, vol. 12. no. 1, pp.17-32 (in Chinese with English abstract).

Gan, X., Zhao. F.. Jin. W, and Sun, D.. 1996. The U-Pb ages of early Proterozoic - Archean zircons captured by igneous rocks in southern China: Geochemica, vol. 25. no. 2, pp. 112-120) (in Chinese with English abstract).

Grabau, A.W., 1923. Stratigraphy of China: Geological Survey of China Publication, Peking, pp.8-9.

Guo, L.Z., Shi, Y.S., and Ma. R.S., 1980. Tectonic framework and evolution of South China: Contributions to Proceedings of International Academic Exchange for Geological Papers. no.1. Geological Publishing Honse. pp. $109-116$.

Hu, X., Xu, J., Tong, C., and Chen, C. 1991. The Precambrian Geology of Southwestern Zhejiang Province: Geological Publishing House. Beijing. $278 \mathrm{p}$ (in Chinese with English abstract).

Hu, X., Xu, J., Chen, C., Li. C., and Li. H.. 1992. Single-grain zircon I-Pb ages for the early Proterozoic granite and pegmatite from southwestern Zhejiang: Chinese Science Bulletin, vol. 37, no. 11, pp.1016-1018 (in Chinese with English abstract). 
Huang, J.Q., 1977, The tectonic framework of China: Acta Geologica Sinica, vol. 51, no. 2, pp.117-135 (in Chinese with English abstract).

Jahn, B.M., Zhou, X.H., and Li, J.L., 1990, Formation and tectonic evolution of Southeast China and Taiwan: Isotopic and geochemical constraints: Tectonphysics, v. 183, pp.145-160.

Jin, W., Zhuang, J., Yang, Z., and Chen, Y., 1992. Characteristics of petrology, geochemistry and metamorphism of the Pre-Caledonian regional metamorphic rocks in Fujian Province: Geology of Fujian, vol. 11, no. 4, pp.241-262 (in Chinese with English abstract).

Li, X.H., Tatsumoto, M., Premo, W.R., and Gui, X.T., 1989, Age and origin of the Tanghu Granite, Southeast China: Results from U-Pb single zircon and Nd isotopes: Geology, vol. 17, pp.395-399.

Li, X.H., Zhao, Z.H., Gui, X.T., and Yu, J.S., 1992, Sm-Nd and zircon U-Pb isotopic constraints on the age of formation of the Precambrian crust in Southeast China: Chinese Journal of Geochemistry, vol. 11, no. 2, pp.111-120.

$\mathrm{Li}, \mathrm{X} . \mathrm{H} ., 1996$, A discussion on the model and isochron ages of $\mathrm{Sm}-\mathrm{Nd}$ isotopic systematics: Suitability and limitation: Acta Geologica Sinica, vol. 31. no. 1, pp.97-104 (in Chinese with English abstract).

Li, X.H., Liu, Y., Tu, X., Liu, H., and Ling, X., 1996, Multiple-stage evolution of zircon U-Pb isotopic systematics in S-type granites and its chronological significance: a case study on Sanfang Granite, northern Guangxi: Acta Mineralogica Sinica, vol. 16, no. 2, pp.170-177 (in Chinese with English abstract).

Liu, Y.. Liu, H.C., and Li, X.H., 1996. Simultaneous and precise determination of 40 trace elements in rock samples by ICP-MS: Geochemica, vol. 25 , no. 6, pp.552-558 (in Chinese with English abstract).

Paterson, B. A., Stephens, W. E., Rogers, G., Williams, I. S., Hinton, R. W., and Herd, D. A., 1992, The nature of zircon inheritance in two granite plutons: Transactions of the Royal Society of Edinburgh: Earth Sciences, vol. 83. pp.459-471.

Pearce, J.A.. 1982. Trace element characteristics of lavas from destructive plate boundaries. In: Thorpe, R.S., ed., Andesites: Wiley, Chichester. pp.528-548.

Ren, J., Jiang, C., Zhang, Z., and Qin, D., 1987, Geotectonic evolution of China: Science Press, Beijing, 203p.

Shui, T., 1987, Tectonic framework of the southeastern China continental basement: Science in China, Ser. B, vol. 30, no. 4, pp.414-422 (in Chinese).
Wang, Y., Yang, J., Guo, L., Shi, Y., Hu, X., and Wang, X., 1992, The discovery of the lower Proterozoic granite in Longquan, Zhejiang Province. and the age of the basement: Geological Review, vol. 38 , no. 6, pp.525531 (in Chinese with English abstract).

Williams, I. S., and Claesson, S., 1987. Isotopic evidence for the Precambrian provenance and Caledonian metamorphism of high-grade paragneisses from Seve Nappes, Scandinavian Caledonides, II. Ion microprobe zircon U-Th- Pb: Contributions to Mineralogy and Petrology, vol. 97. pp.205217.

Williams, 1. S., 1992, Some observations on the use of zircon U-Pb geochronology in the study of granitic rocks: Transactions of the Royal Society of Edinburgh: Earth Sciences, vol. 83. pp.447-458.

Winchester, J. A., and Floyd, P. A. 1976, Geochemical magma type discrimination: application to altered and metamorphosed igneous rocks: Earth and Planetary Science Letters, vol. 28, pp.456-469.

Xie, J.R., 1961, On the tectonics of China: Acta Geologica Sinica,, vol. 41, no. 2, pp.218-239 (in Chinese).

Zhang, W.Y., 1959, An outline of Tectonics of China: Science Press, Beijing, $320 \mathrm{p}$ (in Chinese).

Zhou, X.H. 1997, Isotope geochemical constraints on the tectonic evolution of southeastern China. In: Yu, J.S. et al., eds., Isotope Geochemical Research of China: Science Press, Beijing, in press (in Chinese).

\begin{abstract}
Xian-hua Li is a senior research fellow at Guangzhou Institute of Geochemistry, Chinese Academy of Sciences. He has been working on isotope geochronology and geochemistry of various rock types in SE China since receiving his $P h D$ in 1988 from Institute of Geochemistry, Chinese Academy of Sciences.
\end{abstract}

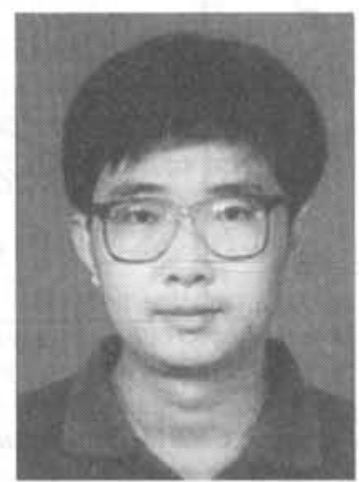

\section{Hutchison 'Young Scientist' Fund}

William Watt Hutchison, "Hutch" to his many friends around the world, was a Scots-born Canadian geologist who served Canada and the IUGS in myriad dynamic and creative ways. Most notably, he served as the IUGS Secretary General (19761980) at a pivotal time in its history, and as IUGS President (1984-1987). The same boundless energy, enthusiasm, skill in communications, and ability to foster teamwork that characterized his work with the IUGS also carried him to preeminent scientific administrative positions in the Canadian Government, where he served as Director General of the Geological Survey of Canada and as Assistant Deputy Minister of Earth Sciences. His distinguished career was terminated in 1987 by his untimely death at the age of 52 , following a painful struggle with cancer.

One of Hutch's last wishes was to establish under IUGS auspices a memorial foundation intended to promote the professional growth of deserving, meritorious young scientists from around the world by supporting their participation in important IUGS-sponsored conferences. The first 3 beneficiaries of the Hutchinson "Young Scientist Foundation" attended the 28th International Geological Congress (IGC) in Washington, D.C., in 1989.

Currently, income earned as interest on the Hutchison fund is insufficient to sustain comparable grants every four years without seriously eroding the principal. For that reason, the IUGS made no grants from the fund for the 30 th IGC, preferring instead to strengthen the fund by allowing it to earn interest for a longer period of time and by appealing for donations from the international geologic community. It is expected that grants from the fund will again support deserving young scientists to attend the 31 st IGC in the year 2000. The Hutchison "Young Scientist Foundation" is a worthy cause that honors a fine, caring man and a distinguished, public-spirited scientist and administrator. The foundation also celebrates and promotes those things that gave Hutch the most professional satisfaction: geology, international scientific collaboration, and stimulating young minds.

The IUGS welcomes contributions to the Hutchison "Young Scientist Foundation." Please send donations to:

Dr. John A. Reinemund

P.O. Box 890

Leesburg, VA 20178 USA

Fax: + 17037774463

Tel: +1 7037771491

Checks in US dollars or Visa/Mastercard (please include account number and expiration date) are preferred in order to avoid the high cost of currency conversions. Residents of the U.S.A. are reminded that charitable gifts of this nature are tax deductible. 